\title{
USE OF CORTICOSTEROIDS AND THE OUTCOME OF INFANTS WITH BRONCHOPULMONARY DYSPLASIA
}

\author{
Marta M. G. B. Mataloun, Maria Augusta C. Gibelli, Ana V. Kato, Flávio Adolfo \\ Costa Vaz and Cléa Rodrigues Leone
}

RHCFAP/2988

MATALOUN, MMGB et al. - Use of corticosteroids and the outcome of infants with bronchopulmonary dysplasia. Rev. Hosp. Clín. Fac. Med. S. Paulo 54 (6): 175-180, 1999.

SUMMARY: Ventilator-dependent premature infants are often treated with dexamethasone. Several trials showed that steroids while improve pulmonary compliance and facilitate extubation, some treated infants may have adverse effects, such as alterations of growth curves. We conducted this retrospective study to evaluate the effects of steroids on mechanical ventilation, oxygen therapy, hospital length stay and mortality, in ventilator-dependent infants with bronchopulmonary dysplasia (BPD) (defined as the need of oxygen supplementation at 28 days of life). Twenty-six newborns with BPD were evaluated during $9-42$ days postpartum (mean $=31$ days) and were divided into two groups: Group I -14 newborns that did not receive dexamethasone, and Group II -12 newborns that received dexamethasone at $14-21$ days of life. Dexamethasone was given at a dose of $0.25 \mathrm{mg}$ per kilogram of body weight twice daily intravenously for 3 days, after which the dose was tapered.

Results - There were no statistically significant differences in the mean length of mechanical ventilation (Group I -37 days, Group II - 35 days); oxygen supplementation (Group I — 16 days, Group II -29 days); hospital stay (Group I -72 days, Group II — 113 days); mortality (Group I — $35.7 \%$, Group II - 41.6\%).

At birth, Group II was lighter (BW: Group I -1154 grams \pm 302, Group II -791 grams $\pm 165 ; \mathrm{p}<0.05$ ) and smaller (height: Group I — 37.22 $\mathrm{cm} \pm 3.3$, Group II $-33.5 \pm 2.4 ; \mathrm{p}<0.05)$ than Group I.

At 40 weeks, there were no statistically significant differences between groups in relation to anthropometric measurements.

Conclusions - The use of corticosteroids in bronchopulmonary dysplasic infants may influence the somatic growth during its use. However, after its suspension, a recovery seems to occur, suggesting that its influence could be transitory.

DESCRIPTORS: Dexamethasone therapy. Bronchopulmonary dysplasia.

Corticosteroids have been used to treat premature infants with bronchopulmonary dysplasia. Possible mechanisms of corticosteroid action include: stabilization of cell and lysosomal membranes ${ }^{1}$, increment of surfactant synthesis ${ }^{2}$, inhibition of prostaglandin and leukotriene synthesis ${ }^{3}$, decrease in polymorphonuclear cell recruitment to the lung ${ }^{4,5}$, enhancement of beta adrenergic activity ${ }^{6}$, reduction of pulmonary and bronchial interstitial fluid ${ }^{7}$.

Several randomized clinical trials of postnatal corticosteroids in premature infants with bronchopulmonary dysplasia have been performed ${ }^{8-21}$. Despite a variety of study designs, some studies report that corticosteroids improve pulmonary compliance and facilitate extubation ${ }^{10,11,15,18}$, reduce the use of mechanical ventilation ${ }^{8-17}$ and the length of oxygen therapy ${ }^{11,13,14,16,19}$.

Besides other adverse effects, reduced growth ${ }^{13,15,17}$ has been described as a consequence of corticosteroid treatment.

The purpose of the present study was to analyze the influence of corticosteroid therapy on the outcome and

From the Department of Pediatrics, University of São Paulo School of Medicine, São Paulo Brazil. growth of premature infants with bronchopulmonary dysplasia.

\section{PATIENTS AND METHOD}

A retrospective study was carried out at the Nursery Annexed to the Maternity, at the University of São Paulo School of Medicine, from January 1993 to December 1997.

Inclusion criteria: All ventilator-dependent very low birth weight infants admitted to the BAM-HC, with bronchopulmonary dysplasia (oxygen dependency at 28 days of life and clinical and radiologic findings) $)^{22}$ and ges- 
tational age under 37 weeks were eligible for the study.

Dexamethasone schedule: The ventilator-dependent very low birth weight infants were scheduled to receive dexamethasone at 14-21 days of life.

Starting in 1993, dexamethasone was administered intravenously every 12 hours for 42 days, according to the following schedule: $0.5 \mathrm{mg} / \mathrm{kg} / \mathrm{day}$ (days 1-3), then tapered by $10 \%$ of initial dose every three days until 0.1 $\mathrm{mg} / \mathrm{kg} /$ day.

Starting in 1995, dexamethasone was administered at a dose of $0.5 \mathrm{mg} /$ $\mathrm{kg}$ /day for 3 days per week from the $14^{\text {th }}$ day of life until 36 weeks postconceptual age or the termination of mechanical ventilation or oxygen therapy.

Starting in November 1997, dexamethasone was administered every 12 hours for 9 days, according to the following schedule: days 1 to 3 from the $14^{\text {th }}$ day of life $-0.3 \mathrm{mg} / \mathrm{kg} /$ day; days 4 to $6-0.2 \mathrm{mg} / \mathrm{kg} /$ day; and days 7 to $9-0.15 \mathrm{mg} / \mathrm{kg} / \mathrm{d}$.

The preterm infants enrolled in the study were subdivided into two groups: Group I - without corticosteroid administration, and Group II — with corticosteroid administration.

Gestational age was determined by the date of the last normal menstrual period, and verified by clinical evaluation using the Dubowitz method ${ }^{23}$. When the clinical assessment differed from the calculated gestational age by two weeks or more, the definitive gestational age was based on clinical assessment. Infants were classified as adequate for gestational age (AGA) if their birth weights were below the $90^{\text {th }}$ percentile and above the $10^{\text {th }}$ percentile on the Ramos intrauterine growth curve $^{24}$, and small for gestational age if their birth weights were below the $10^{\text {th }}$ percentile on the same curve ${ }^{25}$.

The primary outcome measures were: the time of extubation, length of mechanical ventilation and supplemen- tal oxygen, hospital stay, and rate of mortality.

The secondary outcome measure was the pattern of growth.

Chest X-ray studies were performed on admission, as clinically indicated, and at 28 days of life.

Anthropometric measurements were performed at birth and once per week of infant life until discharge. Weight was measured with the infant naked on an electronic scale (Filizzola, São Paulo) to the nearest gram (g). Crown-heel length was measured with the person holding the head of the infant using a wooden measuring board with a fixed headboard and a movable foot board $(\mathrm{cm})$. Cephalic circumference (largest occipito-frontal circumference) was measured with a glass fiber measuring tape $(\mathrm{cm})$.

\section{STATISTICAL ANALYSIS}

Data were entered into Epi Info 6.04 for analysis. Group differences were analyzed with the use of Student's T and Mann-Whitney tests for continuous variables and chi-square test for discrete variables. To control potentially confounding variables, a stratified analysis for birth weight and gestational age was done.

Growth rates were estimated by comparisons of means (Student's T test) for weight, length, and cephalic circumference at birth, 36, and 40 weeks postconceptual age.

\section{RESULTS}

During the period of study, among the 1065 infants with respiratory insufficiency, 35 (3.3\%) developed bronchopulmonary dysplasia, and $26(80 \%)$ of these were enrolled in the study.

Infants with bronchopulmonary dysplasia were subdivided into two groups: Group I - infants that did not receive corticosteroids (14 infants), and Group II - infants that were treated with corticosteroids (12 infants).

Group II was smaller $(\mathrm{p}<0.05)$ and younger $(\mathrm{p}<0.05)$ (Table 1$)$. Other population characteristics in the two groups were similar (sex; color; antenatal corticosteroid therapy; fiveminute Apgar score < 6; inhalation therapy with $b_{2}$ adrenergic, furosemide, and aminophylline) (Table 1).

There were no differences in the

Table 1 - Population characteristics.

\begin{tabular}{lccc}
\hline & Group I ( $=14)$ & Group II (n=12) & Whole ( $\mathrm{n}=26)$ \\
\hline Birth weight $(\mathrm{g})$ & $1154.28 * \pm 30239$ & $791.66^{*} \pm 16579$ & 966.92 \\
Gestational age (weeks) & $31 * * \pm 219$ & $29 * * \pm 185$ & 301 \\
Male/Female & $10 / 4$ & $8 / 4$ & $18 / 8$ \\
White/ No White & $10 / 4$ & $8 / 4$ & $18 / 8$ \\
SGA/AGA & $10 / 4$ & $8 / 4$ & $18 / 8$ \\
5-minute Apgar<6 & $42 \%$ & $58 \%$ & $50 \%$ \\
Aminophylline & $100 \%$ & $100 \%$ & $100 \%$ \\
Furosemide & $86 \%$ & $84 \%$ & $85 \%$ \\
b adrenergic & $14.3 \%$ & $50 \%$ & $43 \%$ \\
Antenatal corticosteroid & $21 \%$ & $25 \%$ & $23.1 \%$ \\
\hline p $<005 * *$ p $<05$ & & & \\
SGA - small for gestational age & AGA - adequate for gestational age &
\end{tabular}


number of days of mechanical ventilation, oxygen requirement, length of hospital stay (Fig 1), and death rates (Group I - 35.\% and Group II $41.6 \%$ ) between the groups studied.

At birth, the group that received corticosteroids (Group II) was lighter (birth weight : Group I $-1154 \mathrm{~g} \pm$ 302, Group II - 791g $\pm 165 ; \mathrm{p}<0.05$ ) (Fig 2) and smaller (height : Group I $-37.22 \mathrm{~cm} \pm 3.3$, Group II $-33.5 \mathrm{~cm}$ $\pm 2.4, \mathrm{p}<0.05$ ) (Fig 3) than the nonsteroid treated group (Group I).

Because Group II was lighter and younger, stratified analysis was done $(\mathrm{BW}<=1120 \mathrm{~g}$ and $>1120, \mathrm{GA} \leq 32$ weeks and $>32$ weeks). There were no differences between groups in relation to variables analyzed (length of time ventilation, CPAP, oxygen therapy, length of hospital stay, and death rates). Therefore, the differences among groups in birth weight and gestational age did not influence the results.

At 36 weeks, the infants in Group II were lighter than those in Group I (weight: Group I - $1247 \mathrm{~g} \pm 308$, Group II $-965 \mathrm{~g} \pm 134, \mathrm{p}<0.05)$ (Fig 2). At 40 weeks, there were no differences in weight and height between the groups (Fig 3). Concerning cephalic circumference, there was no difference between the groups (Fig 4). At 40 weeks, both groups had weights below a $-5.00 \mathrm{Z}$ score, and had heights below a $-9.48 \mathrm{Z}$ score.

\section{DISCUSSION}

This study shows that corticosteroids given to infants with bronchopulmonary dysplasia that were ventilatordependent did not change the length of mechanical ventilation, CPAP, and oxygen therapy. Also, dexamethasone therapy did not reduce mortality or length of hospitalization. As all infants were undergoing mechanical ventilation at 36 weeks postconceptual age, corticosteroids probably did not modify the severity of the disease.

Several limitations of this study require further discussion. The corticosteroid group was lighter and younger than control group, and this could have influenced the outcome measures used in this study. However, after controlling for birth weight and gestational age in the stratified analysis, corticosteroid management did not affect the primary outcome measures in this study.

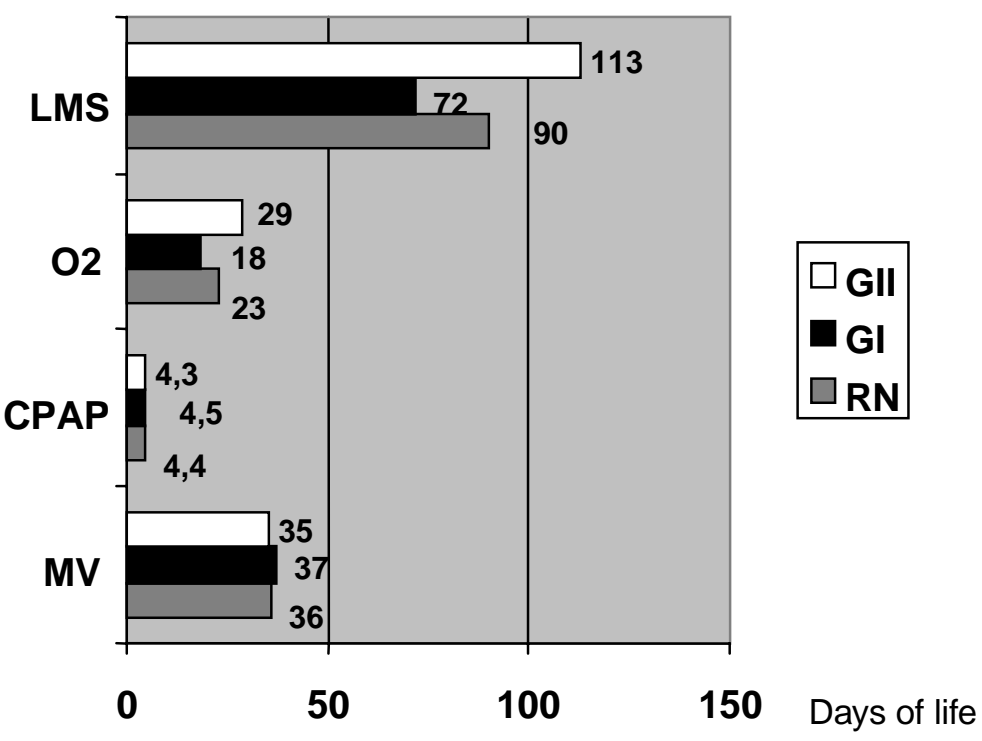

Figure 1 - Neonatal outcome of infants with bronchopulmonary dysplasia. LMS - Length of hospitalization stay; O2 - oxygen therapy duration; CPAP - continuous positive airway pressure; MV - mechanical ventilation.

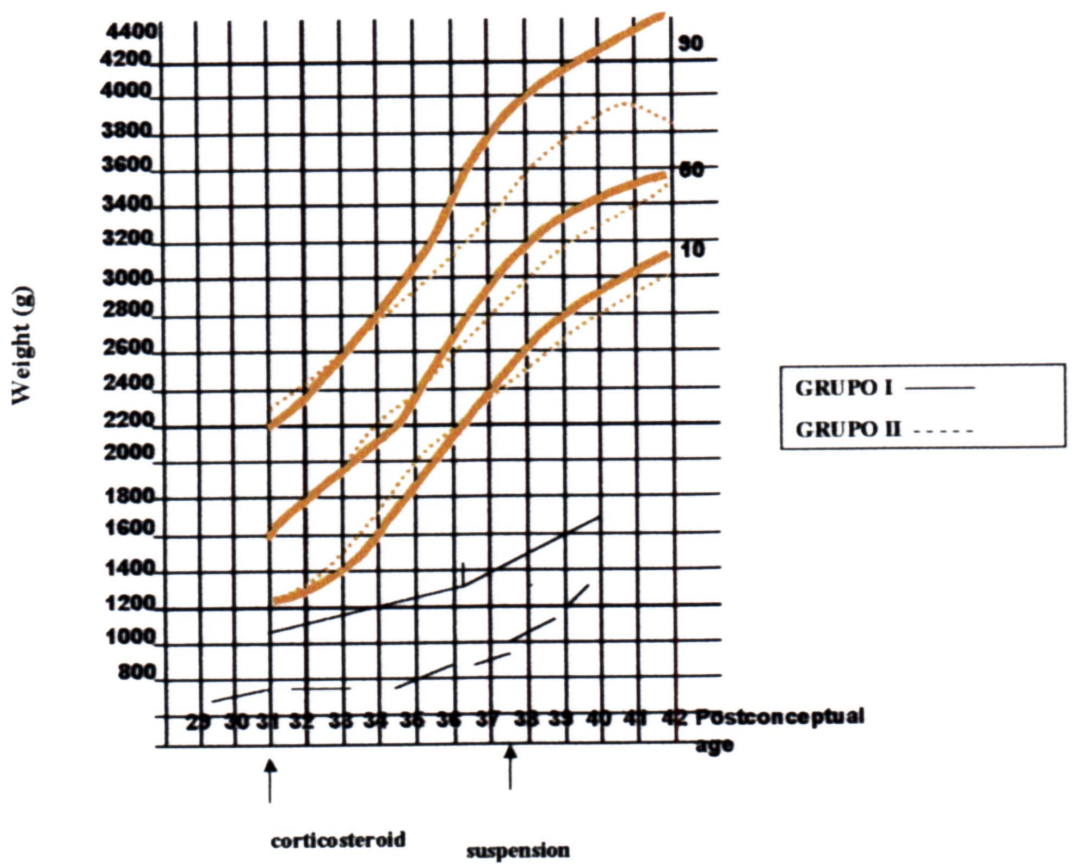

Figure 2 - Weight (g) at birth, 36 and 40 weeks postconceptual of newborns with BPD (Ramos, 1983). 
Concerning somatic growth, although the infants treated with corticosteroids were lighter and smaller at birth than infants that did not receive corticosteroids, we observed that after suspension of dexamethasone use, the somatic growth rates of treated infants recovered, so that at 40 weeks, their anthropometric measurements did not differ significantly from the infants that did not receive corticosteroids. Therefore, adverse effects of dexam-

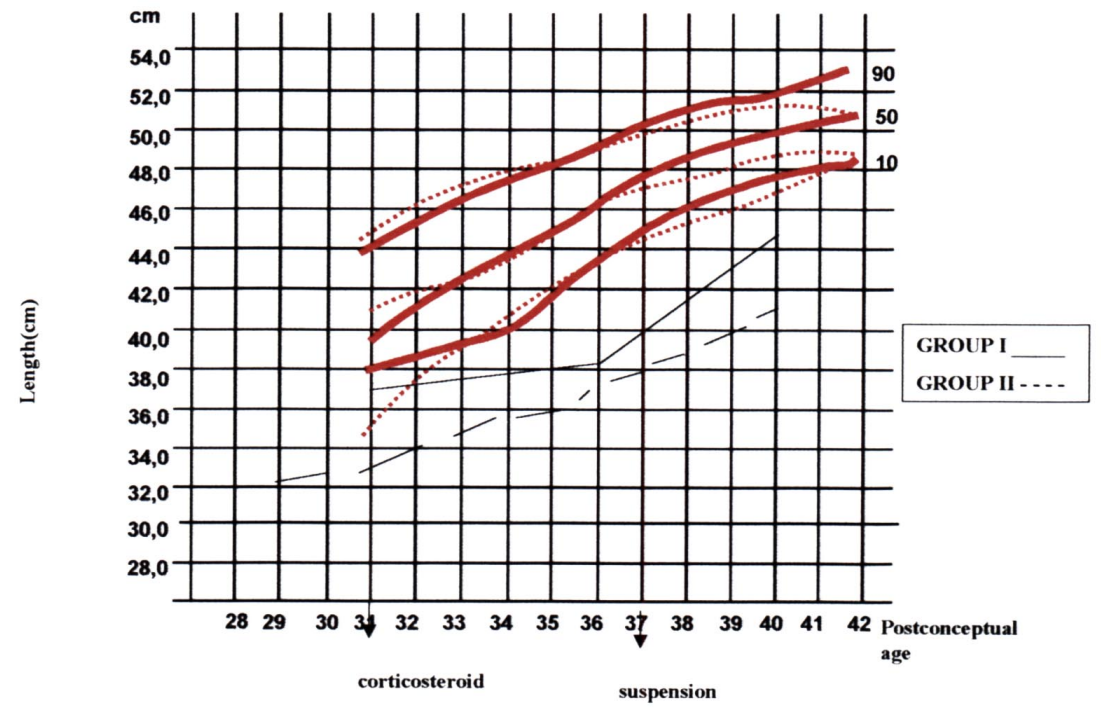

Figure 3 - Length $(\mathrm{cm})$ at birth, 36 and 40 weeks postconceptual of newborns with BPD (Ramos, 1983).

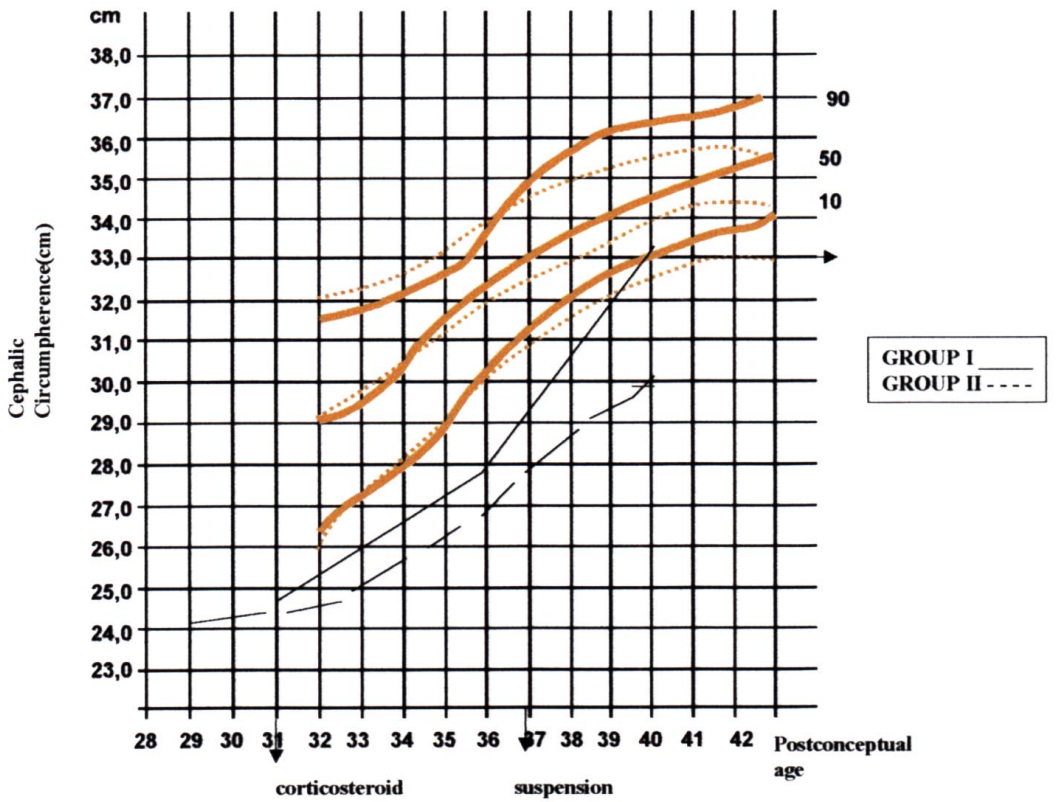

Figure 4 - Cephalic circumference $(\mathrm{cm})$ at birth, 36 and 40 weeks postconceptual of newborns with BPD (Ramos, 1983). ethasone on growth rates are possibly transitory.

Many studies have provided evidence of acute improvement in lung function - increase in dynamic lung compliance ${ }^{10,15,18}$ and easier, earlier extubation $^{10,11,13-18,26}$ — when corticosteroids were used.

Corticosteroids have been used to prevent or treat bronchopulmonary dysplasia since $1978^{8}$, and now they are increasingly being used, probably because of their anti-inflammatory activity.

The studies concerning systemic corticosteroid use for prevention or treatment of bronchopulmonary dysplasia can be subdivided according to the postnatal age at onset of treatment: early - 96 hours, moderately early 7 to 14 days, and delayed $->3$ weeks $^{27}$.

Studies with moderately early onset of systemic corticosteroid use showed a significant reduction in neonatal mortality up to 28 days postpartum, and a significant reduction in chronic lung disease at both 28 days postpartum and 36 weeks post-conception. Also observed were an earlier extubation, and the infants were less likely to require late treatment with dexamethasone ${ }^{11,19,28}$.

Studies with delayed onset of treatment with systemic corticosteroids showed only earlier extubation and reduced length of oxygen therapy. However, they showed no effects on mortality ${ }^{10,13,14,16,17}$.

The absence of improvement in the respiratory conditions, length of hospital stay, and mortality seen in this study could be explained, in part, by the time of onset of corticosteroid therapy between 14 and 21 days postpartum which is between the moderately early groups and the delayed groups reported in the literature.

Several studies showed that dexamethasone delays growth rate ${ }^{13,15,17}$, and one study also has shown a significant 
decline in the growth of cephalic circumference ${ }^{26}$. Dexamethasone treatment resulted in increased amino acid oxidation and decreased muscle protein synthesis in the piglet model ${ }^{29}$. Others did not observe influence of corticosteroids on growth ${ }^{30}$.

In summary, the use of corticosteroids in bronchopulmonary dysplasic infants appeared to impair somatic growth during its use. However, after its suspension, a growth recovery was detected, supporting the hypothesis that growth-related corticosteroid effects could be transitory.
MATALOUN, MMGB e col. - Uso de Corticosteróides e evolução de recém-nascidos com displasia broncopulmonar. Rev. Hosp. Clín. Fac. Med. S. Paulo 54 (6): 175180, 1999.

Recém-nascidos (RN) pré-termo dependentes de ventilação mecânica são frequentemente, tratados com corticosteróides. Vários estudos demonstraram que o uso de corticosteróides melhora a complacência pulmonar e facilita a extubação. No entanto, o uso de corticosteróides é associado, também, a alguns efeitos colaterais, como alterações na curva de crescimento dos recém-nascidos. Nós realizamos um estudo retrospectivo, para avaliar os efeitos dos corticosteróides sobre a duração da ventilação mecânica, oxigenoterapia como também sobre o tempo de internação e mortalidade, em recém- nascidos com displasia broncopulmonar dependentes de ventilação mecânica (DBP) (definida como necessidade de suplementação de oxigênio até 28 dias de vida). Foram analisados 26 $\mathrm{RN}$ com DBP e divididos em 2 grupos: grupo I - $14 \mathrm{RN}$, que não receberam dexametasona e grupo II - $12 \mathrm{RN}$ que receberam dexametasona a partir de 14 a 21 dias de vida, durante 9 a 42 dias ( média - 31 dias). Administrou-se dexametasona, endovenosa, em uma dose inicial de $0,25 \mathrm{mg} / \mathrm{kg}$ dividida em duas tomadas durante 3 dias, e após diminuiu-se a dose até suspensão.

Resultados: Não se observou diferenças significantes em relação à duração da ventilação mecânica (grupo I37 dias e grupo II - 35 dias), suplementação de oxigênio (grupo I 16 dias e grupo II - 29 dias), tempo de permanência no hospital (grupo I - 72 dias , grupo II - 113 dias), e mortali- dade (grupo I - 35,7\%, grupo II $41,6 \%$ ).

O grupo II tinha menor peso de nascimento ( PN- Grupo I - 1154 gramas \pm 302 e grupo II - 791 gramas \pm $165 ; \mathrm{p}<0,05)$ e menor comprimento ao nascimento (Comprimento- grupo I$37,22 \pm 3,3$ e grupo II $-33,5 \pm 2,4$; $\mathrm{p}<0,05)$ em relação ao grupo I. Com 40 semanas, não se observou diferenças significantes entre os grupos com relação às medidas antropométricas.

Conclusão: O uso de corticosteróides em RN com displasia broncopulmonar, pode influenciar o crescimento somático durante o seu uso. No entanto, após sua suspensão parece ocorrer uma recuperação do crescimento, sugerindo que sua influência pode ser transitória.

DESCRITORES: Dexametasona. Displasia broncopulmonar.

\section{REFERENCES}

1. WILSON JW - Treatment and prevention of pulmonary cellular damage with pharmacologic dose of corticosteroid. Surg Gynecol Obstet 1972;134:678-681.

2. DELEMOS RA, SHERMATA DW, KENILSON JH et al. - Acceleration of appearance of pulmonary surfactant in the fetal lamb by administration of corticosteroids. Am Rev Respir Dis 1970; 102:459-461.

3. HONG SCL \& LEVINE L - Inhibition of arachidonic acid release from cells as the biochemical action of anti-inflammatory corticosteroid. Proc Natl Acad Sci USA 1976; 3:1730-1734.

4. WANG JY, YEH TF, LIN YJ et al. - Early postnatal dexamethasone therapy may lessen lung inflammation in premature infants with respiratory distress syndrome on mechanical ventilation. Pediatr Pulmonol 1997;23:193-197.
5. FOX RB, HOIDAL JR, BROWN DM et al. Pulmonary inflammation factor and polymorphonuclear leukocytes. Am Rev Respir Dis 1981;123:521-523.

6. SMITH JA, TABACHNIK E, DUNCAN WJ et al. Pulmonary function and bronchial hyperreactivity in long-term survivors of bronchopulmonary dysplasia. Pediatrics 1981;68:336-340.

7. RUSH MG \& HAZINSKI TA - Current therapy of bronchopulmonary dysplasia. Clin Perinatol 1992;19(3):563-590.

8. KRAMER LI \& HULTZEN C - The role of steroids in early bronchopulmonary dysplasia. Pediatr Res 1978;12:564A.

9. MAMMEL MC, GREEN TP, JOHNSON DE et al. - Controlled trial of dexamethasone therapy in infants with bronchopulmonary dysplasia. Lancet 1983;1:1356 -1358. 
10. AVERY GB, FLETCHER AB, KAPLAN M et al. - Controlled trial of dexamethasone in respirator-dependent infants with bronchopulmonary dysplasia. Pediatrics 1985;75:106-111.

11. CUMMINGS JJ, D'EUGENIO DB \& GROSS SJ. - A controlled trial of dexamethasone in preterm infants at high risk for bronchopulmonary dysplasia. $\boldsymbol{N}$ Engl J Med 1989;320:1505-1510.

12. GLADSTONE IM, EHRENKRANZ RA \& JACOBS HC - Pulmonary function tests and fluid balance in neonates with chronic lung disease during dexamethasone treatment. Pediatr 1989; 84:10721076.

13. HARKAVY KL, SCANLON JW, CHOWDRY PK et al. Dexamethasone therapy for chronic lung disease in ventilator- and oxygen-dependent infants: a controlled trial. J Pediatr 1989; 115:979-983.

14. KAZZI NJ, BRANS YW \& POLAND RL - Dexamethasone effects on the hospital course of infants with bronchopulmonary dysplasia who are dependent on artificial ventilation. Pediatr 1990; 86:722-727.

15. YEH TF, TORRE JA \& RASTOGI A, et al. - Early postnatal dexamethasone therapy in premature infants with severe respiratory distress syndrome: a double-blind, controlled study. J Pediatr 1990; 117:273-282.

16. COLLABORATIVE DEXAMETHASONE TRIAL GROUP Dexamethasone therapy in neonatal chronic lung disease: an international placebo-controlled trial. Pediatr 1991; 88:421-427.

17. OHLSSON A, CALVERT S, HOSKING M et al. Randomized controlled trial of dexamethasone treatment in very-low-birthweight infants with ventilator-dependent chronic lung disease. Acta Paediatr 1992; 81:751-756.

18. BRUNDAGE KL, MOHSINI KG, FROESE AB et al. - Dexamethasone therapy for bronchopulmonary dysplasia: improved respiratory mechanics without adrenal suppression. Pediatr Pulmonol 1992; 12:162 -169.

19. BROZANSKY BS, JONES JG, GILMOUR CH et al. - Effect of pulse dexamethasone therapy on the incidence and severity of chronic lung disease in the very low birth weight infant. J Pediatr 1995; 126:769-776
20. RASTOGI A, AKINTORIN SM, BEZ ML et al. - A controlled trial of dexamethasone to prevent bronchopulmonary dysplasia in surfactant-treated infants. Pediatrics 1996; 98:204-210.

21.ZACHMAN RD, SAMUELS DP, BRAND JM et al. - Use of the intramuscular relative-dose-response test to predict bronchopulmonary dysplasia in premature infants. Am J Clin Nutr 1996; 63:123-129.

22. BANCALARI E, ABDENOUR GE, FELLER R - Bronchopulmonary dysplasia: clinical presentation. J Pediatr 1979; 95:819-823.

22. DUBOWITZ L, DUBOWITZ V, GOLDBERG C - Clinical assessment of gestational age in the newborn infant. J Pediatr 1970; 77:1.

23. RAMOS JLA - Avaliação do crescimento intra-uterino por medidas antropométricas do recém-nascido São Paulo, 1983, 180p Tese de Doutoramento - Faculdade de Medicina da Universidade de São Paulo.

24. BATTAGLIA FC \& LUBCHENCO LO - A practical classification of newborn infants by weight and gestational age. J Pediatr 1967; 71:159-161.

25. PAPILE LA , TYSON JE, STOLL B et al. - A multicenter trial of two dexamethasone regimens in ventilator-dependent premature infants. N Engl J Med 1998; 338:1112-1118.

26. HALLIDAY HL - Clinical trials of postnatal corticosteroids: inhaled and systemic. Biol Neonate 1999; 7( suppl 1):29-40.

27. KOVACS L, DAVIES GM, FAUCHER D et al. - Efficacy of sequential early systemic and inhaled corticosteroid therapy in the prevention of chronic lung disease of prematurity. Acta Paediatr 1998; 87:797-798.

29. MICKELSON BD, BENEVENGA NJ \& GREER FR - Dexamethasone negatively impacts nitrogen metabolism and growth in newborn piglets. Ped Res 1998;265A:1550.

30. VAN WEISSENBRUCH MM, FERREIRA IA , LAFEBER HN et al. Growth during the first two years of life in preterm infants who developed bronchopulmonary dysplasia (BPD) and received initial dexamethasone therapy. Ped Res. 1998; 200A:1169.

Received for publication on the 06/12/99 